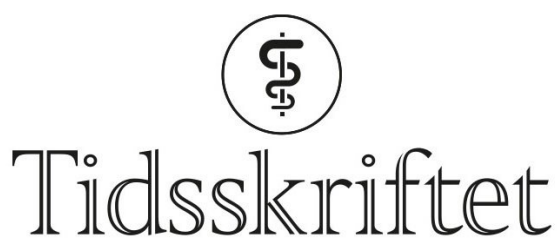

DEN NORSKE LEGEFORENING

\title{
Correction: Not both genders, but all genders
}

RETTELSE

KETIL SLAGSTAD

Tidsskr Nor Legeforen 2018; 138. doi: 10.4045/tidsskr.18.0888.

The title should be: Not both genders, but all genders.

The following sentence should read: Biologically speaking, we all fall somewhere along a spectrum of gender, of which male and female represent the extreme ends.

Also, this sentence should read: In recent years, the increased genetic insight into the biology of sex development has chipped away at the binary model of sex and gender on several levels.

Finally, this sentence should read: In any case, an increasing amount of knowledge is available with regard to the biological complexity of sex and gender, and proof that the binary model of sex and gender finds no support in biology (10).

We apologise for the error, which has been corrected in the online version.

Publisert:16. november 2020. Tidsskr Nor Legeforen. DOI: 10.4045/tidsskr.20.0929

C Tidsskrift for Den norske legeforening 2020. Lastet ned fra tidsskriftet.no 